\title{
Modernização, Estado e Questão Agrária
}

\author{
Moacir Palmeira
}

A vasta literatura que se tem ocupado das mudanças por que passou o campo brasileiro nas últimas décadas dá especial atenção, e não sem razão, à chamada modernização da agricultura. Na verdade contrariando previsōes dos analistas das décadas de 50 e 60, o setor agrícola, a partir de finais dos anos 6u, absorveu quantidades crescentes de crédito agrícola, incorporou os chamados "insumos modernos" ao seu processo produtivo, tecnificando e mecanizando a produçāo, e integrou-se aos modernos circuitos de comercializaçāo. $O$ aumento da produtividade permitiu o aumento da produção de matérias-primas e alimentos para a exportação e mesmo para o mercado interno. Mesmo a produçáo de alimentos para abastecimento das cidades, apesar de dificuldades que toriam a ver com orientaçōes da política econômica, teria sido, no entender de alguns estudiosos, "bastante razoável"( GRAZIANO da SILVA, 1987, p.25). A alteração da base técnica da agricultura, associada à sua articulação "com a indústria produtora de insumos e bens de capital para a agricultura, e por outro, com a indústria processadora de produtos naturais" levou à formação do chamado "complexo agroindustrial" (DELGADO, 1985, p.19; SORJ, 1980, p.29-30) ou à "industrialização da agricultura" ( GRAZIANO da SILVA, 1987, p.19) $)^{1}$.

Essa modernização, que se fez sem que a estrutura da propriedade rural fosse alterada, teve, no dizer dos economistas, "efeitos perversos": a propriedade tornou-se mais concentrada, as disparidades de renda aumentaram, o êxodo rural acentuou-se, aumentou a taxa de exploração da força de trabalho nas atividades agrícolas, cresceu a taxa de auto-exploraçāo nas propriedades menores, piorou a qualidade de vida da população trabalhadora do campo. Por isso, os autores gostam de usar a expressāo "modernização conservadora".

Sem querer minimizar a importância desse processo, procuraremos chamar a atençäo neste trabalho para alguns outros processos sociais que, desenvolvendo-se mais ou menos no mesmo período, menos ou mais articulados com $o$ que é descrito como modernização, mas guardando autonomia, contribuíram, tanto quanto aquela alteraçāo da base técnica da produção em vastos segmentos do campo brasileiro, para conformar o perfil atual deste último e configurar os problemas hoje socialmente vividos como importantes pela populaçäo, especialmente por aquelas configuraçōes de interesses que, em posiçōes antagônicas no espectro social, vinculam seus destinos ao destino da parte agrária do país,

1 Quando da primeira redação deste artigo, ntio conhecfamos ainda o livro de Delgado (1985, p. 62-3, 149), que pensa o CAI (complexo agroindustrial) năo apenas como na integraç̧⿸丆 técnica, mas em termos de integraçăo de capitais intersetoriais, sugere que a propria noção de "setor agrícola" fica comprometida nesse processo. Agradeço a Jose Francisco Graziano da Silva a indicaçăo que, como ficara patente ao longo do texto, foi da maior importancia. 
mesmo que suas motivaçōes pouco tenham de agrárias ou que nāo tenham um projeto para a agricultura e desconfiem de que exista tal entidade. Em muitos casos, as motivações econômicas dos capitalistas que investem na agricultura, qualquer que seja a origem de seus capitais, residem menos na perspectiva de aí realizar lucros maiores do que em outros setores da economia ou, a exemplo dos rentiers clássicos, de daí retirar uma renda em nada incompatível com os seus lucros, do que na perspectiva de uma aplicação de dinheiro comparativamente vantajosa, dentro dos marcos de uma determinada política econômica e considerada a conjuntura do mercado, a outras aplicaçōes financeiras (DELGADO, 1985, parte II). Já para os trabalhadores rürais, não se trata simplesmente de representar a agricultura (ou a "lavoura", como se dizia numa outra época) mas de acabar com a articulação hierarquizada de interesses que se pensa debaixo desse termo. $O$ projeto em que investem é um projeto de classe, não é um projeto de setor, e a sociedade vislumbrada em suas manifestaçōes nāo cabe nos limites da agricultura.

Os processos que vamos abordar não são ignorados pela literatura da modernização. Ao contrário, a maior parte das informaçōes com que vamos trabalhar foram buscadas nesses textos. No exercício que vamos fazer, o que muda é a autonomia, atribuída, até segunda ordem, a cada um desses processos, e as implicaçōes sociais, essas efetivamente nāo extraídas pelos autores, pelo menos de uma forma sistemática, da ocorrência de tais processos.

\section{A Expropriação do Campesinato}

Nos últimos quarenta anos, o perfil da distribuiçāo espacial da população brasileira sofreu profunda alteração. Entre 1940 e 1980, inverteram-se os percentuais das populaçōes rural e urbana, a primeira caindo de aproximadamente $70 \%$ da populaçāo total para cerca de $30 \%$, enquanto a segunda aumentava de $30 \%$ para $70 \%$.

As migraçōes internas foram as grandes responsáveis pelo crescimento urbano e o IBGE estima que, em 1970, de 30 milhöes de migrantes, total acumulado de residentes em municípios distintos daqueles em que nasceram, 21 milhōes "se dirigiram para as áreas urbanas" (FIBGE, 1979, p.23). George Martine, levando em consideração também a migração rural-urbana intramunicipal estima que 7.299.000 migrantes se deslocaram do campo para a cidade na década de 60 e 11.003 .000 nos anos 70 (MARTINE, 1984, p.203).

$O$ crescimento das migraçōes do campo para a cidade nāo foi linear. Nos anos 60 , por exemplo, o fluxo migratório sofreu uma queda em seu ritmo que voltou a acelerar-se na década seguinte. A homogeneidade desse processo também é discutível. No mesmo período, as cidades médias passaram a ter um papel importante como receptoras de migrantes e houve um certo redirecionamento regional das migraçōes. Ainda nos anos 60 , uma mudança importante ocorreu com relaçāo aos períodos anteriores: as migraçōes interurbanas revelaram-se mais importantes que as migrações do campo para a cidade. Mas, nos anos 70, embora mantendo-se a supremacia daquelas, o fluxo de migrantes rurais teve um crescimento significativo (FIBGE, 1979, p.24; MARTINE, 1984)².

2 Martine chama a atençāo para possfveis problemas estatisticos nessas variaçbes, mas nf̌́o chega a negar que elas tenham, efetivamente, ocorrido.
As migraçōes internas foram as grandes responsarveis pelo crescimento urbano e o IBGE estima que, em 1970, de 30 milhoes de migrantes, total acumulado de residentes em municipios distintos daqueles em que nasceram, 21 milhôes "se dirigiram para as areas urbanas". 
Por outro lado, isso que os autores gostam de designar como "êxodo rural" é anterior à modernização da agricultura, tanto em termos de fluxos objetivos, como a simples leitura dos dados censitários sugere, quanto em termos de sua percepção pela sociedade como um problema. Alfredo Wagner Berno de Almeida (1977, p.41-42), analisando a literatura que, entre 1930 e 1972, tratou do "êxodo rural", assinala que o marco temporal adotado pelos autores é 1930. A partir daquele ano, começaria a se dar o esvaziamento do campo, atribuído ora às secas do Nordeste, ora à industrialização, ora à urbanização... Em torno da mecanizaçāo agrícola que, em alguns estados, começa a tomar impulso nos anos 40-50, discute-se se é causa ou conseqüência do êxodo. Já Aspásia Camargo, referindo-se ao 20 Governo Vargas, lembra que "cedo a oposição desperta para o problema agrário. Muitos, assustados pelos visíveis efeitos de um acelerado êxodo rural que altera a fisionomia das grandes capitais, transferindo para elas os graves problemas que afligem o campo, conclamam a adoçāo de medidas governamentais corretivas" (CAMARGO, 1981, p.148). A mesma autora deixa clara, ao longo de seu trabalho, a estreita vinculaçāo estabelecida entre o êxodo rural e o problema agrário durante as discussões em torno da reforma agrária no período anterior a 1964. Provavelmente, esses deslocamentos de população têm acompanhado diferentes tipos de crises no setor agropecuário e os movimentos, nem sempre regulares, de crescimento das atividades econômicas nas cidades que, conjugados ou nāo àqueles, exercem alguma atração sobre determinados segmentos da população rural.

O que há de novo no "êxodo rural" das décadas mais recentes é que, embutido nele, está a expulsāo sistemática de trabalhadores rurais de diferentes categorias $^{3}$ do interior dos grandes domínios. É verdade que a expulsāo de trabalhadores dependentes (moradores, agregados, colonos ou semelhantes) também já ocorria no passado, mas o processo a que nos referimos tem características muito peculiares. Se, no passado, o trabalhador expulso encontrava casa e trabalho em condiçōes semelhantes numa outra propriedade, ou mesmo, num momento seguinte, reconstituía a primeira relação, na expulsão recente a saída da propriedade é definitiva e sem substituiçāo ou, dito de uma outra maneira, é o mesmo tipo de contrato tradicional ${ }^{4}$ que é liquidado.

Não nos parece pois desprovido de sentido falarmos de expropriação do campesinato. Trata-se menos de despojamento dos trabalhadores rurais de seus meios de produção, pois destes, de alguma maneira, já haviam sido ou sempre estiveram expropriados, mas de sua expropriação de relaçōes sociais, por eles vividas como naturais, que tornam viável sua participação na produçāo e sobre as quais, por isso mesmo, exercem algum controle que se traduz num certo saber fazer.

3 Salvo referencia expressa em contrário, empregaremos os termos trabalhador rural e camponês como equivalentes, como se tornou usual no Brasil nos ultimos anos, af incluídos os assalariados permanentes e temporários, os parceiros e os arrendatários, bem como os posseiros e os pequenos proprietários familiares, que nâo estāo em questáo neste momento, mas de que, logo a seguir, trataremos.

4 O tipo de contrato que vinculava, no passado, entre o morador e o proprietário da terra era muito mais que um simples contrato de trabalho. $O$ que o trabalhador potencial procurava num engenho ou numa fazenda era uma casa de morada e isso e que the permitia trabalhar para o patrab, em troca de alguns dias de trabalho gratuito semanal ou pagos a um valor inferior aos demais, ou ter acesso a uma pequena extensäo de terra para cultivo próprio, mediante o pagamento de uma quantia fixa em dinheiro e alguns dias de trabalho gratuito anuais. Era a morada que assegurava tambem ao trabalhador acesso à água, à lenha e, eventualmente, a madeira e aos pastos da propriedade e o inseria numa relaçåo de divida permanente com o proprietário. (Palmeira, 1976, p. 305-315; Sigaud, 1979, p. 33-36; Garcia Jr., 1983, cap. II e 1986; Heredia, 1986, cap. VII; Almeida e Esterci, 1979 e Bastos, 1977b). 
Os dados censitários, na sua precariedade, indicam uma nítida e progressiva diminuiçâo do número de empregados permanentes, parceiros e outras condiçôes, categorias que descrevem os trabalhadores residentes dentro das propriedades, que de cerca de $40 \%$ do pessoal ocupado nos estabelecimentos agropecuários em 1940 passaram para cerca de 13\% em 1980, embora, para os primeiros, seja registrado um certo crescimento entre 1970 e 1980 . Os empregados temporários, que, via de regra, indicam trabalhadores assalariados nãoresidentes dentro dos estabelecimentos, são subestimados pelos Censos, em que pese a importância que lhes tem sido atribuída por estudos específicos realizados nos últimos 20 anos. Segundo o Censo Agropecuário eles, que seriam 1.183 .870 em 1940 , correspondendo a $10,43 \%$ do pessoal ocupado na agropecuária, teriam passado a $2.767 .880 \mathrm{em} 1980$ ou $13 \%$ do total desse ano. Ângela Kageyama (1986, p. 77), todavia, remanejando os dados dos dois últimos censos, estimou os temporários em 3,4 milhōes para 1975 e em 4,5 milhōes para 1980.

O caráter geral dessa verdadeira expropriaçāo do campesinato ${ }^{5}$ revela-se no momento em que, até mesmo nas áreas de fronteira agrícola em expansão, as expulsōes de posseiros deixam de ser apenas episódios de uma trajetória que pode terminar, embora não necessariamente, com a conquista definitiva de um pedaço de terra (VELHO, 1972, cap. 7) para dar lugar a uma "urbanização" precoce (GRABOIS, 1971) que sinaliza o "fechamento da fronteira" para os trabalhadores (GRAZIANO da SILVA, 1982, cap. 6) ${ }^{6}$. Mais ainda, o alcance da expropriação aparece quando a própria reprodução da pequena propriedade estável no sul do país começa a ser ameaçada pela falta de alternativas para as novas geraçōes, o latifúndio limitando sua fixação como pequenos proprietários na própria regiāo e reduzindo-se as possibilidades de migração para o centro ou o norte; mas também por seu endividamento junto aos bancos e pela inviabilização dos economicamente mais fracos no bojo do processo de competição que se instala com a entrada do grande capital em circuitos sobre os quais, anteriormente, os agricultores tinham um relativo controle (PEIXOTO et al., 1979; FIGUEIREDO, 1984, p. 163; CORADINI, 1982). Paradoxalmente, as modernas cooperativas, que se expandem no sul do país, asseguram ao pequeno agricultor menor controle do mercado do que os intermediários tradicionais, mesmo yuando lhes asseguram maiores ganhos (CORADINI, 1982, p. 59-60; DELGADO, 1985, p. 164-190).

Se, no último caso, há uma certa associação entre a expropriação do campesinato e a chamada modernização da agricultura, é preciso nāo se esquecer que se trata de um movimento independente e, via de regra, anterior à própria modernizaçāo. Tanto é assim que, escrevendo em 1967 sobre as "favelas rurais", expressão espacial da expulsão dos anos recentes, Maria Isaura Pereira de Queiroz (1978, p. 221-222) refere-se ao seu aparecimento, em princípios do século, no Rio Grande do Sul, "associado às transformaçōes do trabalho dentro das estâncias de gado, principalmente com a paulatina cercadura dos campos e das propriedades" e ao seu desenvolvimento, em meados dos anos 50 , no norte

5 Para um paralelo entre essa expropriação e o processo classico ver Sigaud, Os clandestinos e os direltos, 1979, p. 35-6; e, numa ótica um pouco diferente, Martins, Expropriação e violência: a quéstäo politica no campo, 1980, p. 16-7.

6 Para uma crítıca à idéia de "fechamento da fronteira" ver Martins, op. cit., p. 17-8 e, do mesmo autor, A reforma agrária e os limites da democracia na "Nova República", 1986, cap. 6.
Os dados censitários, na sua precariedade, indicam uma nftida e progressiva diminuição do número de empregados. permanentes, parceiros outras condiçöes, categorias que descrevem os trabalhadores residentes dentro das propriedades, ... 
do Paraná e em São Paulo, com a substituiçāo do cultivo de produtos agrícolas para exportação pela pecuária. Celso Furtado (1964, p. 149-151) e Manuel Correia de Andrade (1964, p. 169-170) falam da expulsão de moradores, com características semelhantes, na década de 50 e início dos anos 60 , da zona da mata nordestina, com a expansão dos canaviais provocada pelo aumento do consumo interno e pela retomada das exportaçōes de açúcar. Pesquisas mais recentes têm vinculado a expulsão de moradores, agregados, posseiros e outros trabalhadores, em diferentes regiões do país, à substituição de produtos agrícolas (BASTOS, 1977b, cap. II; GRYNSPAN, 1987, p. 58-60); à incorporaçāo de novas terras por um produto comercial tradicional (HEREDIA, 1986); à especulação imobiliária (GRYNSPAN, 1987, p. 41-60); à substituição da agricultura pela pecuária (GARCIA Jr., 1975 e 1983, p. 352-354; ALMEIDA e ESTERCI, 1979; BASTOS, 1977b; GRAZIANO da SILVA, 1978, p. 91-92; MARTINS, 1980, p. 45-66; GRYNSPAN, 1987) ou aos lances da luta de classes no campo (PALMEIRA, 1979, p. 41-55; SIGAUD, 1979; GARCIA Jr., 1986). O que a mecanização, a criação de uma infra-estrutura custosa (de que a irrigação é o melhor exemplo) e a utilização sistemática dos chamados insumos modernos, bem como os padróes gerenciais centralizadores que introduzem, vão fazer é criar, para além da impossibilidade estrutural de restabelecimẹto dos contratos tradicionais provocada pela expropriação, uma limitaçāo de ordem técnica.

A expropriação, assim concebida, nāo implica, necessariamente, em proletarização. Ainda que ela possa ser condição para a oferta dos "braços dóceis de um proletariado livre", a que se refere Marx (1950, p. 174) à indústria ou à agricultura moderna, não se trata de uma fatalidade. Ela pode viabilizar a formação de um proletariado mas, por si só, não o produz. Assim, a expulsão dos camponeses do interior das grandes propriedades não impediu que os pequenos produtores entre 1940 e 1988 aumentassem em número mais que qualquer outra categoria de trabalhador rural - os "responsáveis e membros não-remunerados da família" entre 1940 e 1980 passaram de 5,7 milhōes, pouco mais de 50\% do total, para 15,6 milhōes, quase $74 \%$ de todo o "pessoal ocupado nos estabelecimentos agropecuários" (FIBGE, 1986, p. 281) - ainda que também fossem atingidos pela expropriaçāo, uma "expropriaçāo indireta" (MARTINS, 1981, p. 141). Mas o que é importante reter é que, sendo um processo que envolve luta", a expropriação não tem um resultado certo e, em determinadas circunstâncias, a ruptura das relaçōes sociais tradicionais é a condição mesma para que o trabalhador dependente transforme-se num camponês autônomo, mesmo que, em condiçōes precárias e por pouco tempo; como também, por paradoxal que possa parecer, que o acesso à propriedade de uma parcela de terra pode ser, muitas vezes, não a preliminar da expropriação, como no caso anterior, mas a expressão dela própria, ao implicar na liquidação da possibilidade de acesso do novo proprietário à mata, à lenha, à água, a pastos de utilização coletiva, etc. (ESTERCl, 1985, p. 124-156). Por isso mesmo, não tem sentido pensá-la em ter-

\footnotetext{
7 Para uma visão dc problema de compatibilidade entre os dados dos diferentes censos e, especialmente, entre Censos Agropecuários e Censos Lemográficos, ver também o trabalho de Graziano da Silva, $A$ modernizaçâo dolorosa, 1982, cap. 8 e Ary Silva Jr., Emprego rural: uma análise critica das categorias dos Censos agropecuários e das estatísticas cadastrais, 1984, p. 115-63.

8

Martins (198'1, p. 123) chamou a atenção, com ir uita propriedade, para'o crescimento no número de posseiros, os "ocupantes" dos Censos, entre 1970 e 1975, um provável resultado da resistência daqueles trabalhadores à expulsão.
} 
mos de uma adequação funcional antecipatória a uma posterior proletarização ou, muito menos, o que se tornou mais freqüente nos últimos anos, abordá-la simplesmente como um efeito perverșo da modernização.

Se insistimos na dissociação entre expropriação e modernização e na distinção entre expropriação e proletarização é menos pela obsessão do rigor conceitual do que pela intenção de chamar a atençāo para certos efeitos que são específicos da expropriação.

Assim, se a simples saída de migrantes das áreas rurais já contribui para criar desequilibrios nas estruturas sociais que servem de suporte, entre outras, às atividades econômicas, com a expulsão sistemática de trabalhadores dos grandes domínios rurais e a inviabilização da pequena propriedade, em algumas áreas, são as próprias estruturas que são transformadas. A desvinculação do trabalhador de suas condiçōes de produçāo tradicionais, ao mesmo tempo que impede sua reprodução social como agregado, morador ou colono, mesmo que aqui e ali essas designaçōes continuem sendo usadas com significados diferentes do passado, provoca a alteração do "sistema de posições e oposições sociais" (BOURDIEU, 1966, p. 215) que circunscreve as práticas sociais suas e dos grupos com que se relaciona.

Para citar apenas um exemplo: a oposição fundamental entre morador e senhor de engenho, na zona canavieira nordestina, pessoal, exclusiva, só admitindo mediadores que contribuíssem para a sua plena realização, espacialmente circunscrita, com a expulsão, cede lugar a um conjunto de oposiçōes sociais em que ela permanece fundamental, mas, por assim dizer, muda de natureza.

A figura do senhor de engenho, destituída de seus atributos anteriores, passa a ter diante dela não mais um somatório de moradores individualizados mas uma "força de trabalho segmentada" (SIGAUD, 1979, p. 128-131) entre fichados, que tendem a coincidir com os trabalhadores ainda residentes nas propriedades, e clandestinos, que correspondem tendencialmente aos trabalhacures expulsos e hoje residindo nas pontas de rua das cidades e povoados. Essas novas oposiçōes (proprietário-fichado; proprietário-clandestino e fichadoclandestino) não são fechadas nem espacialmente circunscritas, como era a relaçāo morador-senhor de engenho. Ao contrário, supōem-se mutuamente e supōem outras relaçōes, mormente com a figura do empreiteiro (arregimentador de mão-de-obra) que se torna 0 mediador entre trabalhadores clandestinos e proprietários. $\mathrm{O}$ empreiteiro, por sua vez, ao mesmo tempo que se opōe socialmente ao proprietário e ao "trabalhador de ponta de rua", e indiretamente ao trabalhador residente no engenho (com quem o trabalhador que recruta vai competir), depende de um certo tipo de comerciante local, o "dono de venda" (SIGAUD, 1983) que o financia diretamente, mas sobretudo de forma indireta, ao vender mantimentos a crédito aos seus trabalhadores. Estabelece-se dessa maneira uma outra oposiçāo, entre trabalhadores do empreiteiro e "donos de venda". Por outro lado, o antigo morador, rompido o contrato que estabelecia com o senhor de engenho, a quem hoje apenas vende sua força de trabalho, como mediador único com o mundo fora dos engenhos, é posto também na condição de vendedor da produção de seu sítio e/ou de pequeno intermediário nas feiras da região (PALMEIRA, 1971; GARCIA, 1984) onde compete com o pequeno proprietário de áreas próximas e com o trabalhador de ponta de rua,

\footnotetext{
... as implicaçōes do

fato de a

modernizaçăo ter sido

tocada pelo Estado

sāo, via de regra, deixadas de lado, em

favor de um discurso

que, explifita ou

implicitamente, credita tais mudanças a um empresariado moderno, urbano que foi ao campo ou a um empresariado rural que, sabe-se lá por que razöes (...) modernizou-se.
} 
que também atuam no pequeno negócio, fundindo-se com eles na oposição ao comércio estabelecido, onde, na maioria das vezes, abastecem a si próprios e aos grandes proprietários enquanto consumidores ${ }^{9}$. É do jogo entre essas diversas relações que vai resultar, a cada momento, o peso relativo de cada uma das categorias sociais que se articulam em torno das diferentes posiçōes nos vários mercados que se estabelecem, mercado de trabalho, mercado de terras, mercado de produtos e - por que não? - mercado político (GARCIA Jr., 1986, p. 31-32, $39-40)^{10}$. Note-se que não se trata apenas do desdobramento de papéis antes desempenhados pelos mesmos personagens sociais, nem tão somente da aproximação (ou da colocação em relação) de posições sociais antes, por assim dizer, vinculadas a universos sociais diferentes, mas também do aparecimento de posiçōes e personagens novos, capazes de gerar interesses novos e de produzir grupos que assumam como seus esses interesses mas que só existem porque diminuíram as distâncias entre esses diferentes universos e porque se estruturou um novo sistema de posições.

É plausível supor que rearranjos sociais equivalentes tenham ocorrido naquelas áreas onde a literatura chama a atenção para a emergência de figuras novas como o bóia-fria ${ }_{2}$ o novo camponês tecnificado, o camponês integrado, o culaque de fronteira e outras tantas.

\section{Estado: ação e presença}

A ação do Estado tê. que estudaram a agricultura brasileira ou por quem analisou o processo de modernização. No entanto, as implicaçōes do fato de a modernização ter sido tocada pelo Estado são, via de regra, deixadas de lado, em favor de um discurso que, explícita ou implicitamente, credita tais mudanças a um empresariado moderno, urbano que foi ao campo ou a um empresariado rural que, sabe-se lá por que razões (talvez por já ser pensado como sendo um empresariado, ainda que enrustido) modernizou-se. Essa fábula do empresário rural moderno pode ser ilustrada por uma reportagem especial recentemente publicada numa das maiores e mais influentes revistas de circulaçāo semanal do Brasil. (VEJA, 1989, p. 106-110). Mas tanto os documentos governamentais quanto muitas das análises feitas por economistas e cientistas sociais tendem a tratar o setor privado e o Estado como entidades estranhas uma à outra. Todos ressaltam, não há dúvida, o peso dos empresários na condução dos negócios do Estado. Mas as relações entre ambos são pensadas em termos de representação e influência. Se essa modalidade de pensar já se mostrava inadequada para entender o funcionamento do Estado brasileiro de antes do período autoritário, mais insuficiente ainda se revela quando se trata de entender como tem operado esse Estado nas décadas mais recentes, como mostram os trabalhos de René Dreifuss (1981) e Fernando Henrique Cardoso (1975).

9 Do lado dos grandes proprietários operam-se também deslocamentos no gênero, mas não há espaço para abordá-los nos limites deste artigo. Sua análise pode ser encontrada em Heredia (1986) e Garcia Jr. (1986).

10

Uma análise cuidadosa da formação desses mercados e de sua articulação pode ser encontrada no artigo de Afrânio Raul Garcia Jr., "Industrialização e transformaçôes sociais no campo", Museu Nacional, 1987, estranhamente alterado em sua publicação no volume $O$ mercado de trabalho brasileiro: estrutura e conjuntura, Ministério do Trabalho/Instituto de Economia Industrial (UFRJ), s/1, abril de 1987. 
É díficil pensar a modernização da agricultura conduzida pelo Estado sem pensar as transformações sofridas pelo próprio Estado. É necessário não propriamente elaborar uma teoria do moderno Estado brasileiro, de que os cientistas políticos vêm se ocupando com menor ou maior sucesso, mas procurar indicar, ainda que de modo aproximativo, o que tem sido a ação do Estado no campo, analisar os meios através dos quais essa ação se tem dado e sobretudo explorar as suas implicações. Mas isso não basta. É preciso pensar o que a simples presença do Estado no campo tem significado.

Na primeira metade da década de 60 foi elaborada uma legislação específica para o campo. O primeiro passo foi o Estatuto do Trabalhador Rural, em 1963. A seguir, vieram o Estatuto da Terra, em 1964, possivelmente a peçachave do novo aparato jurídico, e toda uma extensa legislação complementar. Criou-se também uma legislação previdenciária que teve efeitos importantes a partir do início dos anos 70 .

A perspectiva comumente adotada na abordagem dessas leis, tomadas isoladamente ou agregadas segundo a preferência do analista, gira em torno de quatro questões: "Quem fez?"; "A quem serviu?" e, se o observador se põe mais à esquerda, "Foi ou não cumprida?", ou, então, se ele prefere se colocar à direita, "Era ou não adequada à nossa realidade?". Essas perguntas, no seu aparente bom senso, talvez se constituam no grande obstáculo à percepção sociológica de um fato novo: uma legislação que passou a existir.

Tanto o Estatuto do Trabalhador Rural quanto o Estatuto da Terra e seus desdobramentos foram resultado de um longo processo de lutas sociais e políticas (CAMARGO, 1981). Longe de representarem a imposição unilateral da vontade de um grupo, refletiram um jogo de conflitos e composiçöes entre os interesses dos setores sociais envolvidos com a questão da terra ou dos direitos trabalhistas, ao mesmo tempo que expressaram as alterações nas "composiçōes de poder e estilos de populismo" que desembocaram no golpe militar de 1964 (id. ibid., p. 224). Nunca é demais lembrar que esse processo de luta não parou com o Estatuto da Terra ou qualquer outra peça jurídica posterior. Ao longo do

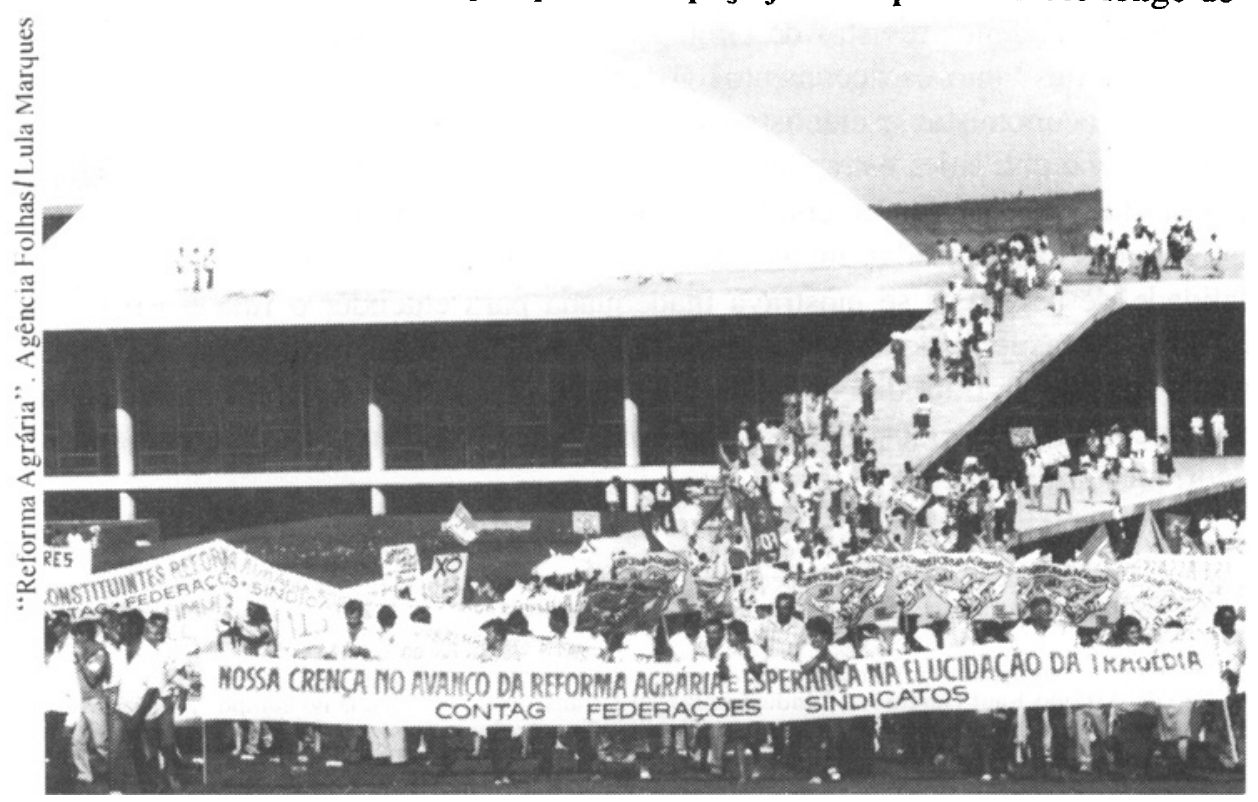


regime autoritário e no período subseqüente, o jogo de pressốes e contrapressōes continuou a se fazer, direcionando a legislaçāo mais para um lado ou para outro (PALMEIRA, 1987).

Antes de indicar uma política, a nova legislação impôs um novo recorte da realidade, criou categorias normativas para uso do Estado e da sociedade, capazes de permitir modalidades, antes impensáveis, de intervenção do primeiro sobre esta última. Ao estabelecer, com força de lei, conceitos como latifúndio, minifúndio, empresa rural; arrendamento, parceria, colonização, etc., o Estado criou uma camisa-de-força para os tribunais e para os seus próprios programas de governo, ao mesmo tempo que tornou possível a sua intervenção sem o concurso de mediadores e abriu espaço para a atuação de grupos sociais que reconheceu ou cuja existência induziu. Nesse sentido, independentemente da efetivaçāo de políticas por ela possibilitadas - a reforma agrária, a modernização agrícola, a colonização são exemplos - a nova lei passou a ter existência social a partir da hora em que foi promulgada. Tornou-se uma referência capaz de permitir a reordenação das relaçōes entre grupos e propiciar a formação de novas identidades.

Valeria a pena comparar o Estatuto da Terra com a Lei no 22.631 que criou o Serviço Social Rural (SSR), em 1955. Enquanto esta listava uma série de atribuições para o SSR, que iam da "prestação de serviços sociais no meio rural", visando a melhoria das condições de vida da sua população (alimentação, habitaçāo, saúde, incentivos à atividade produtora) até a aprendizagem de técnicas de trabalho, o fomento à "economia das pequenas propriedades", a criação de "comunidades" e a "realização de inquéritos e estudos", o Estatuto da Terra se propunha a "dar organicidade a todo sistema rural do país (...)". A Mensagem $n^{\circ}$ 33, item 18, encaminhando ao Congresso o projeto da Lei n04.504 de 1964,é explicíta:“'Daí a denominação do projeto que por constituir um verdadeiro Estatuto da Terra visa regular os diversos aspectos da relação do homem com a terra, tratando-os de forma orgânica e global".

Enquanto o SSR era administrado por um Conselho Nacional com um presidente nomeado pelo Presidente da República a partir de uma lista tríplice apresentada pela Confederação Rural Brasileira (que, aliás, possuía a maioria dos membros dos conselhos daquela entidade autárquica), o Estatuto da Terra criou o Instituto Brasileiro de Reforma Agrária (IBRA), diretamente subordinado ao Presidente da República, "localizando na própria chefia da Nação a responsabilidade pela eficiente execução do processo de modernização de nossa estrutura agrária..." (Lei no 4.504, 1964, mensagem no 33, item 28).

No texto da lei que criou o SSR e da grande maioria dos documentos que o antecederam ou lhe deram seguimento (anteprojetos, projetos, emendas, mensagens, pareceres parlamentares e técnicos, manifestaçōes de associaçōes de proprietários rurais, discursos, etc.) o que está em jogo é o meio rural, a população rural, a classe rural, o rurícola, o ruralista, o agrário (assim mesmo, substantivado) ou coisas que tais. Vez por outra, quando se trata de comparações com a indústria (SESI) ou o comércio (SESC), aparece a expressão "trabalhador rural"' (RAPOSO, 1960). Já o Estatuto da Terra está vazado numa retórica muito mais próxima daquela que informava as formulaçōes dos partidários da reforma agrária antes de 1964 . Os termos que utiliza - proprietários rurais, trabalhadores rurais, parceiros, arrendatários, ocupantes, etc. - supōem 
uma diversidade de interesses, negada no caso anterior, e aponta para a possibilidade de políticas específicas para cada uma daquelas categorias, sem a mediação de entidades patronais.

A legislação nāo determina uma política. O Estatuto da Terra, na sua ambigüidade, abre a possibilidade de diferentes vias de desenvolvimento da agricultura e oferece múltiplos instrumentos de intervenção ao Estado. Nos governos que se sucederam após 1964, uma via foi priorizada: a da modernização do latifúndio, em prejuízo daquela que era, aparentemente, privilegiada pela letra do Estatuto, a da formação de propriedades familiares. Bernardo Sorj (1980, p. 107), referindo-se à Amazônia, já havia chamado a atençāo para a não definição a priori da forma que a colonização acabou assumindo na região. Na verdade, seria mais justo dizermos que uma via de transformaçāo do campo foi sendo construlda, à medida mesmo que aqueles instrumentos de intervenção iam sendo acionados em função das diferentes conjunturas do jogo de interesses que se antepōem em torno das questōes ligadas à terra e à produção rurais, que estão longe de ser estáticas ou referidas a um elenco fixo de grupos sociais e instituições.

O lugar estratégico atribuído à especulação financeira e a importância atribuída à exportação de produtos agropecuários e agroindustriais como fonte de divisas para o país, no modelo de desenvolvimento adotado pelo regime militar, foram, certamente, decisivos para a escolha da via da modernização conservadora. Delgado relativiza o papel desempenhado pela agricultura como fonte de divisas. A exportação agrícola, segundo ele, "no início do período, de 1967 até 1979, (...) comanda praticamente a pauta de exportações globais, com participação em torno dos $80 \%$ ". Mas, ao longo da década, há uma diversificação do seu perfil, "com a introdução de novos e importantes produtos agrícolas e, principalmente, produtos agrícolas elaborados pelo setor industrial a jusante da agricultura" (DELGADO, 1985, p. 27). Sua conclusão é que "essa mudança na estrutura do comércio exterior agrícola altera um pouco o enfoque de considerar o setor agrícola como fonte provedora cie divisas para o restante da economia, para fazer realçar também um novo aspecto das relações internacionais do setor agrícola, que é o da integração de relaçōes interindustriais". (id. ibid., p. 26).

É díficil dimensionar o que significou a intervenção do Estado na condução desse processo. Sua abrangência, todavia, não deixa lugar para dúvidas. Há um certo consenso entre os autores de que o grande instrumento de que se valeu $o$ Estado foi o crédito subsidiado. Um estudo recente mostra que o volume real do crédito rural, na primeira metade dos anos 70 , cresceu quase três vezes, permanecendo estável nos anos seguintes, mas os subsídios continuaram crescendo até o final da década, passando a representar cerca de $18 \%$ do valor total da produção agrícola, quando, no início do período, correspondiam a 1 ou $2 \%$. O mesmo trabalho, comparando o volume do crédito concedido com o valor bruto da produção agrícola no mesmo período, aponta evidências de desvio de empréstimos para outras atividades: na segunda metade da década, o valor dos créditos concedidos girava em torno de 70 a $90 \%$ do valor bruto da produção (GRAHAM et al., 1987, p. 22-23). Os dados apontam também para uma crescente concentração de créditos em tomo de um pequeno número de grandes tomadores (id. ibid., p.24-25).
Ao contrário do que geralmente se supöe, a repressīo ao movimento campones e as tentativas de domesticação empreendidas pelo regime militar nāo conseguiram impedir que 0 esforço de organização dos trabalhadores prosseguisce. 
Outro instrumento utilizado generosamente pelos governos foram os incentivos fiscais às atividades agropecuárias e conexas, em especial nas áreas da SUDENE e da SUDAM. Entre 1975 e 1985, os fundos de incentivos fiscais, segundo relatório preparado pela Comissāo de Avaliação dos Incentivos Fiscais (COMIF) divulgado pela imprensa (ABBOTT, 1988, p. 18), "receberam US\$ 6 bilhōes e 620 milhöes". O relatório aponta para a baixa rentabilidade dos projetos, o nāo-cumprimento de seus objetivos de criação de empregos e distribuição de renda: "O Fundo de Incentivos da Amazônia (FINAM) recebeu US\$ 1 bilhão e 100 milhōes, dos quais mais da metade se destinou ao setor agropecuário. Dos empreendimentos agropecuários incentivados, apenas 3\% tiveram alguma rentabilidade - os restantes, prejuízo" (ABBOTT, 1988).

Quanto ao Nordeste, informa o relatório que o "FINOR-agropecuário recebeu US\$ 1,3 bilhão, de 1975 a 1985 , sendo que US\$ 1,157 bilhão se destinaram à pecuária, basicamente para 'modernizar latifúndios' - a média das áreas incentivadas foi de 4.500 hectares, enquanto o tamanho médio dos estabelecimentos rurais do Nordeste é de 37 hectares. Apesar dos recursos, $60 \%$ dos estabelecimentos continuaram como 'latifúndios por exploração', depois de 14 anos, de acordo com o último levantamento do INCRA" (id. ibid.).

O segredo desses investimentos pouco rentáveis está na colocação de grandes somas de recursos em mãos de particulares sem qualquer tipo de risco. O capital próprio, como tivemos ocasião de constatar, é substituído pela alteração do valor cadastral da terra no INCRA. O estudo do COMIF vai falar de um "comércio de incentivos em que as empresas aplicam parte de seu imposto como incentivo, em troca de pagamento daquelas que receberão os recursos, os quais, na verdade, pertencem à União, porque são dívida fiscal" (ABBOTT, 1988). No caso do FINAM, o mesmo documento chama a atenção para o fato de que "apenas $5 \%$ dos projetos não sofreram mudança de controle acionário e a maior parte foi vendida depois do recebimento dos recursos do FINAM, o que caracteriza "uso especulativo dos incentivos' " (id. ibid.).

Um terceiro instrumento de peso na condução da política de modernização foi a política de terras públicas. Respaldados nos dispositivos legais que inibem a propriedade pública de imóveis rurais em caráter permanente (Estatuto da Terra, art. 10, esp. $\$ 1^{\circ}$ ) e em toda uma sublegislação que brotou dentro da burocracia governamental, expressa em portarias, normas, instruçōes, exposiçōes de motivos e até em simples ordens de serviço, os governos do período autoritário operaram uma transferência maciça do patrimônio fundiário da Nação para particulares, sobretudo na Amazônia legal. Dos 126.581.645 hectares adquiridos e incorporados pela Uniāo e pelo INCRA entre 1970 e 1985, 31.829 .966 foram transferidos, em caráter definitivo, sob a forma de propriedades rurais, para particulares ${ }^{11}$. Um dos mecanismos mais usados para operar essa transferência foram as licitaçōes (os leilōes de terras) que beneficiavam, pelo tamanho dos lotes vendidos (500 a 3.000 hectares), pela inexistência de limitaçōes à aquisição de vários lotes por um mesmo grupo ${ }^{12}$ e de exigências como aquelas que se antepóem ao reconhecimento de posses, além da própria mecânica dos leilōes e de todo o ritual envolvido (editais, projetos, etc.) que excluem os que

11 Fonte: Dados gerais sobre a atividade fundiaria ate 1985, INCRA-DF-DFT, março de 1986.

12 Segundo dados da mesma fonte, um único grupo economico adquiriu, em uma única licitaçı, no Território Federal do Amapa, em novembro de 1978, cerca de 160 mil hectares. 
não têm recursos para cobrir lances e os que não dispōem de recursos financeiros e culturais para sequer entrar na parada, que beneficiavam grandes fazendeiros e grupos econômicos nacionais e estrangeiros interessados na terra como reserva de valor. Dos quase 32 milhöes de hectares a que nos referinos, 12.224.984 hectares foram, assim, incorporados ao estoque de terras da grande propriedade. Curiosamente, essa política generosa de alienação de terras públicas a grupos nacionais e estrangeiros se fez acompanhar de um crescente envolvimento das Forças Armadas com o problema fundiário e com a questão da terra ${ }^{13}$.

Nesses números não estāo incluídas as áreas que foram objeto de contratos de concessão de domínio de terras públicas, a respeito dos quais não dispomos senão de informações fragmentárias, que, segundo documento do INCRA (ZANATTA, 1984, p. 187) são "uma forma especial de regularização de áreas de até 600 vezes o módulo de exploração indefinida, cujos títulos apresentem vícios insanáveis", podendo ser realizada sem concorrência - de acordo com o mesmo autor, "uma forma adotada para proteger investimentos pioneiros na Amazônia" - ou através de concorrência pública - "concessão de áreas destinadas a projetos de colonização por empresas particulares" 14.

Para atender a demandas de outros setores da sociedade, o Estado brasileiro desenvolveu ainda políticas, nāo necessariamente vinculadas à agricultura, mas que resultaram em mudanças importantes. Refiro-me, basicamente, à construçäo de grandes obras públicas e, muito especialmente, à construção de grandes hidrelétricas, que provocaram o deslocamento forçado de milhares de famílias, a desativação de toda uma gama de atividades econômicas e alterações significativas na organização social das populaçōes atingidas (SIGAUD et al., 1987). Essas barragens, como também os açudes públicos e as rodovias, que provocaram a valorização das terras próximas, somaram-se às políticas de que falamos anteriormente no estímulo à especulação fundiária.

Acreditamos haver consenso entre os autores a respeito dos efeitos perversos dessas políticas e de seu caráter excludente. Essa tem sido também a visão dos governos que, ao longo dos anos, têm formulado e reformulado planos e programas, e desenvolvido ações mais genéricas ou mais localizadas para contemplar os excluídos. Isso é uma conseqüência não apenas de uma vontade política de compensar aqueles que pagaram um preço tão alto pelo desenvolvimento, mas é, também, uma decorrência da incapacidade dos mediadores tradicionais de absorverem o impacto de um processo de exclusão social de que foram co-fautores quando não do próprio esvaziamento das funções de mediação exercidas pelos grandes fazendeiros operada pela legislação e pela ação do Estado de que foram beneficiários. Ao longo dos últimos 20 anos, sucederam-se os programas especiais, setoriais ou regionais, ou ainda, combinando essas duas características, voltados para o atendimento às populaçōes e áreas carentes.

13 Sobre a questão ver: Almeida, G.E.I A.T. A segurança nacional e o revigoramento do poder regional, 1980; Martıns, A militarização da questāo agrária no Brasili, 1984.

14

exemplo mais conhecido foi a concessāo de 400.000 hectares no Pará, em 1975, à construtora Andrade Gutierrez para a implantação do "Projeto Tucumã”, denunciada, na epoca, pela Confederação Nacional dos Trabalhadores na Agricultura como lesiva aos interesses dos trabalhadores e da Nação. Dez anos depois, segundo matéria publicada pela imprensa: "Invasão e insegurança pöem fim ao sonho de Tucumä", Jornal do Brasil, de 31/05/87, p. 20-21, o empreendimento estaria em crise e seria palco de graves conflitos sociais. 
A principal dessas políticas que tinham como alvo o trabalhador rural foi a política previdenciária. Não terá sido por acaso que a criaçāo e implantação do Prograina de Assistência ao Trabalhador Rural (PRORURAL) coincidiu com a arrancada da modernização da agricultura. O PRORURAL deu existência real ao Fundo de Assistência ao Trabahnador Rural (FUNRURAL), anteriormente criado, estendendo alguns dos benefícios da legislação previdenciária urbana ao campo. Ao contrário de alguns ensaios feitos na área da previdência fural anteriormente, era uma política global para o conjunto dos trabalhadores rurais, ar inclúdos desde o assalariado rural até o pequeno proprietário familiar. O PRORURAL assegurava a participaçāo de sindicatos patronais e de trabalhadores nos seus conselhos e previa a celebração de convênios, para a prestação de serviços de saúde, entre outras instituiçōes, com sindicatos, entidades privadas, etc. (CHIARELLI, 1972). A criação dessa teia de relações envolvendo sindicatos de trabalhadores, sindicatos patronais, hospitais particulares, médicos, associaçōes medicas, prefeituras municipais e representaçōes locais do FUNRURAL seria responsável, depois de alguns anos, por mudanças importantes nas relaçōes sociais no campo e propiciaria, já nos anos 80 , a eclosão de conflitos de certa monta, sobretudo no sul do país (CORADINI, 1988).

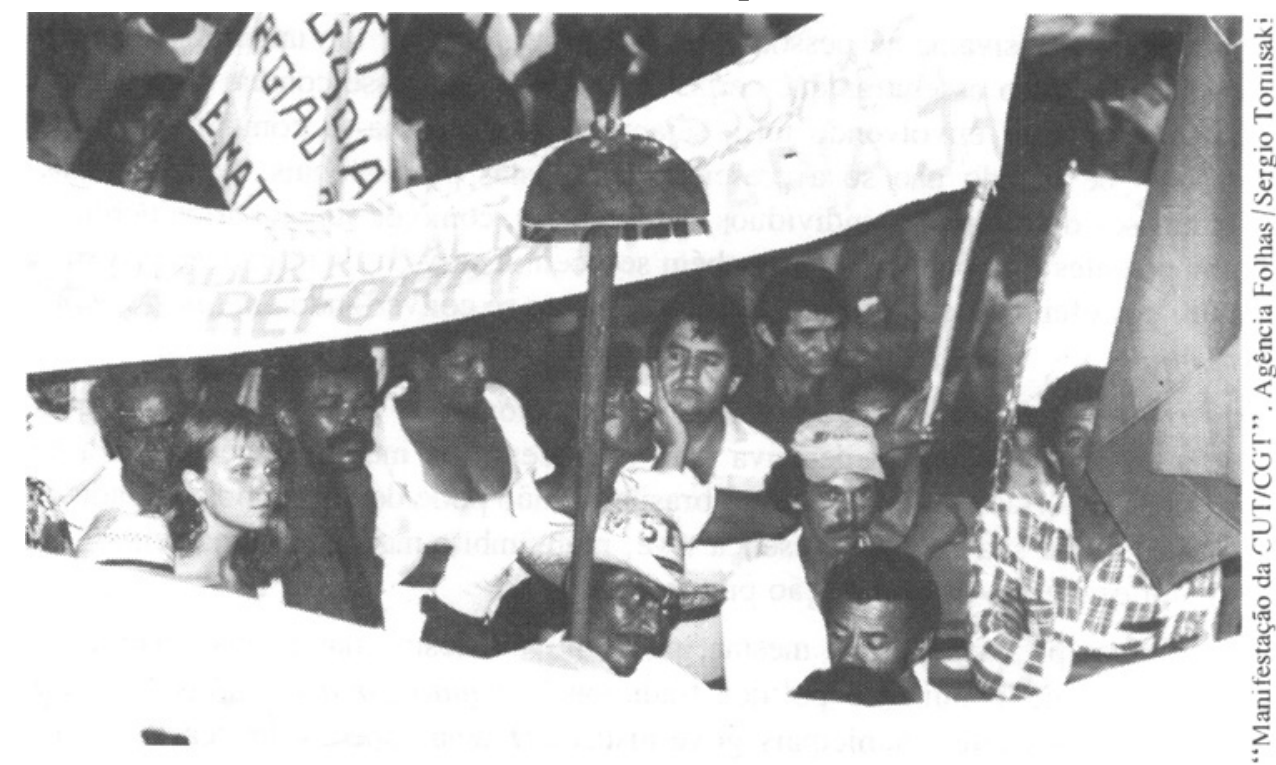

As vantagens oferecidas pelas políticas de modernização beneficiaram os latinfundiários tradicionais mas também atraíram para o campo capitais de outros setores da economia para quem o campo passou a ser colocado como uma alternativa interessante de investimento. Grandes grupos econômicos entraram na produção agrícola ou agroindustrial e passaram a imobilizar capitais em terras, contando não apenas com a sua valorização, mas também com a perspectiva de captação de recursos públicos para a realização de aplicações financeiras mais vántajosas no momento. Graziano da Silva (1982, p.77), analisando, em fins dos anos 70, a expansão da agricultura paulista, assinala que "além de reserva de valor, a terra tem ainda constituído importante meio de acesso a outras formas de riqueza, de que são exemplos típicos o crédito rural e os incentivos fiscais". Sorj (1980, p. 109-110), referindo-se à Amazônia, afirma que a "possibilidade de ganhos extrordinários tem determinado a conduta excepcional de empresas multinacionais, que se caraterizam por não realizar investimentos em 
compras de terras, embora tenham aberto um exceção quanto ao caso brasileiro".

Esse estilo de intervenção do Estado teric um outro efeito: atrair os interesses ligados a esses capitais para dentro da máquina do Estado, que é onde passaram a se dar as decisões e os ajustes econômicos. Se, no passado, os interesses da grande propriedade rural se faziam sentir através do Legislativo e da articulação de clientelas pessoais dentro da burocracia estatal, agora é a própria garantia da condição de proprietário e a própria criação de oportunidades econômicas que passam por dentro da máquina estatal. É como se o mercado de terras passasse a atravessar a máquina do Estado. O Estado deixa de ser apenas um regulador externo desse mercado. Ele se torna também um dos loci e um dos agentes econômicos, ao lado de alguns dos órgãos públicos que o compōem, de alguns de seus funcionários e dos vendedores e compradores de terra convencionais, dessas transaçōes ${ }^{15}$.

Isso fortalece o velho capital agrário, que já dispunha de suas articulações, mas sobretudo propicia uma coalização de interesses, qualquer que seja a origem dos grupos que expressam ou dos recursos que manipulam, em torno da especulação com a terra. As clientelas continuarão existindo, personalizadas, mas não exclusivamente pessoais, porque passa a haver um imperativo de eficácia: é preciso assegurar que certas decisōes de interesse comum para os que fazem negócios envolvendo terra sejam tomadas. Torna-se comum nos organismos de Estado nāo só a presença de lobistas profissionais, representando interesses de diferentes indivíduos ou empresas, como de funcionários públicos competentes e imparciais que também se pöem a serviço de interesses privados que, por efeito de sua própria atuação, acabam se convertendo em interesse público.

A atenção dada à ação planejada, intencional, do Estado no campo, que, sem dúvida alguma, foi decisiva para o processo de modernização técnica de setores importantes da agricultura brasileira, nāo pode deixar na obscuridade os efeitos que a sua simples presença teve, num âmbito mais amplo, no sentido de alterar esquemas de dominação preexistentes.

Essa presença, em si mesma, não é nova. Mesmo nas formas mais estereotipadas de dominação política tradicional, a autonomia extralegal de que gozavam os chefes municipais governistas era uma espécie de "carta branca que o governo estadual outorga aos correligionários locais, em cumprimento da sua prestação no compromisso típico do "coronelismo' " (NUNES LEAL, 1976, p. 51).

O que é novo é uma presença que não passa mais, necessariamente, pela mediação dos chefes locais, diminuindo-lhes o poder, através do esvaziamento de suas funçōes ou pelo reconhecimento ou criação de novos mediadores. Nāo que os mediadores percam necessariamente o controle sob suas clientelas, mas esse controle passa a ser mediatizado pelo controle que terão que exercer sobre determinados postos na máquina do Estado - um Estado mais do que nunca centralizado - tornando-se mais complexo o seu trabalho de dominação. A patronagem exercida pelos grandes proprietários, já abalada pela saída em massa

15 Sobre a necessidade de se estudar o processo regulatório no mercado de terras ver Delgado, op cit., p. 214 e cap. 6 (p. 191-228). 
dos trabalhadores de dentro das fazendas, deixa de ser um mecanismo exclusivo de articulação dos camponeses com o Estado e com a sociedade. Abre-se a possibilidade de patrōes alternativos e de padröes alternativos, ao mesmo tempo que se amplia o espaço para organizaçōes estranhas ao sistema tradicional de dominação.

Se, ao invés do caminho da modernização do latifúndio, outra via de desenvolvimento da agricultura tivesse sido acionada ou imposta por força das lutas sociais, certamente os resultados seriam outros. Mas estamos querendo chamar a atenção para que, independentemente da via tomada, os pressupostos legais da ação do Estado, articulados às próprias transformaçōes por ele sofridas enquanto máquina administrativa, além dos efeitos provocados por sua presença direta no campo, impuseram uma mudança das relações Estado/grandes proprietários/camponeses. $O$ reconhecimento social, operado legalmente pelo Estatuto do Trabalhador Rural, e a possibilidade, aberta pelo Estatuto da Terra, de uma intervenção direta do Estado sobre os grupos reconhecidos como compondo o setor agricola ou a agricultura, permitiriam a elaboraçāo e aplicação de políticas próprias para cada um desses grupos. $O$ camponês - 0 trabalhador rural - tornou-se objeto de políticas, o que até então era impensável, criando-se condiçōes para o esvaziamento das funçōes de mediação entre camponeses e Estado, até então exercida pelos grandes proprietários ou por suas organizaçōes.

O Estatuto do Trabalhador Rural reconheceu a existência do trabalhador rural como categoria profissional, vale dizer, como parte do mundo do trabalho (este, por sua vez, parte de um mundo maior, concebido pela legislação trabalhista, elaborada durante o Estado Novo, dividido entre os interesses conciliáveis do capital e do trabalho). O Estatuto da Terra reconheceu a existência de uma questâo agrária, de interesses conflitantes dentro daquilo que, até então, era tratado como um todo indivisível, a agricultura ou, já convertida ao jargāo corporativista, a classe rural. Mas, ao fazê-lo, tentando identificar várias linhas possíveis de conciliação desses interesses, tentando ordenar as relações na agricultura sem cingir-se a apenas uma de suas dimensōes - a oposição entre latifundiários e camponeses ou assalariados rurais nas formulaçōes reformistas pré64 - acabou alargando o âmbito da questão agrária, ou melhor, criando condiçōes para que no jogo entre a referência legal e a atuação do Estado, de um lado, e os interesses conflitantes de grandes proprietários e trabalhadores, de outro, questōes como a das terras públicas e sua destinação, a da colonização, a do crédito e da relação entre campc reses devedores e bancos credores, a do cooperativismo, a das obras públicas em área rural, problemas como secas e enchentes, entre outros, se incorporassem à concepção de questão agrária dos camponeses e, num certo sentido, também dos grandes proprietários, e se tornassem, cada uma delas, além de objeto de conflitos específicos em pretexto para o questionamento da política global do governo para o campo. existência de uma questáo agrária, de interesses connitantes dentro daquilo que, atc entāo, era tratado como um todo indivisfivel, a agricultura ou, ja convertida ao jargâo corporativista, a classe rural.

\section{A Afirmação Política do Campesinato e a Virada da Igreja}

A implantação dos sindicatos de trabalhadores rurais, que correu paraleła a essa intervenção do Estado, contribuiria de modo decisivo para enfraquecer os padrōes tradicionais de dominação. Antes mesmo de sua atuação, sua sim- 
ples presença ameaçaria aqueles padrōes. $O$ sindicato iria se colocar não só corro um mediador alternativo, mas como um veículo para a implementação de regras impessoais que são a negação da dominação personalizada do latifúndio. Através do sindicato, os trabalhadores puderar ter acesso à Justiça e a implementação das leis tornou-se uma possibilidade real.

Os riscos de absorção dos sindicatos pelos esquemas clientelísticos tradicionais foram minimizados por sua inserção numa estrutura vertical e nacional, aquela do movimento sindical de trabalhadores rurais. Fossem eles entidades meramente locais, o resultado talvez fosse diferente. Mas eles são peças de uma política para cuja elaboração contribuem, mas que só se completa em nível estadual, na programação das federaçōes de trabalhadores rurais, e em nível nacional, na programação de sua confederação.

Outra presença importante, ao longo desses anos, seria a da Igreja Católica. A rigor, a Igreja, como instituição, sempre esteve presente no campo. Mas, se ela permaneceu, como no passado, cobrindo, na formulação de José de Souza Martins, aspectos da vida do trabalhador rural não englobados pelos princípios contratuais que informam a ação de partidos e sindicatos (MARTINS, 1985 , p. 124), mudou o sentido de sua atuação. De suporte das fotmas tradicionais de dominação passou a suporte de contestação camponesa, para o que contribuiu, certamente, seu conflito com o Estado, algum tempo depois de implantado o regime militar, que, por sua vez, intensificou-se com esse posicionamento.

Surgindo como força política na luta pela terra e por direitos trabalhistas nos anos 50, da convergência conflituosa das ligas camponesas e sindicatos rurais, estimulados por partidos de esquerda e pela Igreja Católica, o movimento sindical dos trabalhadores rurais teve um papel fundamental na transformação da questão da reforma agrária em questão política.

Ao contrário do que geralmente se supōe, a repressão ao movime nto camponês e as tentativas de domesticação empreendidas pelo regime $\mathrm{n}$ ilitar não conseguiram impedir que o esforço de organização dos trabalhadores prosseguisse. Por razões já analisadas em outra parte (PALMEIRA, 1985), as entidades sindicais se reorganizaram com relativa rapidez e, ao mesmo tempo que sustentaram lutas que se dispersaram politicamente como decorrência da própria conjuntura nacional, partiram para ampliar e fortalecer sua organização em nível nacional. $O$ cimento ideológico dessa empresa política comandada, a partir de 1968, pela Confederação Nacional dos Trabalhadores na Agricultura, seria a bandeira da reforma agrária.

Usando habilmente a referência legal existente, o movimento sindical conseguiu manter o seu perfil de força autônoma exigindo o cumprimento da lei, contestando publicamente o Governo no campo em que lhe era possível combater (iniciativas governamentais que atingissem diretamente interesses dos trabalhadores rurais), num momento em que praticamente inexistia contestação organizada fora das tentativas armadas: lutando para manter juntos na mesma organizaçāo todos os camponeses (do trabalhador volante ao pequeno proprietário familiar), todos os beneficiários potenciais da reforma agrária. $\mathrm{Na}$ impossibilidade da mobilização política (substituída pela defesa individual dos trabalhadores e pela pressão possível junto aos órgãos do poder), o movimento sindical desenvolveu um intenso trabalho pedagógico em torno da questão da
Embutido no processo de desenvolvimento da organizaçäo sindical, ocorria um outro processo de consequiências igualmente importantes: a elaboração de uma identidade de classe pelos que trabalham no campo. 
reforma agrária como ponto de convergência dos interesses das diferentes categorias de trabalhadores rurais.

Embutido no processo de desenvolvimento da organizaçáo sindical, ocorria um outro processo de conseqüências igualmente importantes: a elaboração de uma identidade de classe pelos que trabalham no campo. A adoção da identidade de camponês significava juntar, em torno da vinculação à terra através do trabalho, pessoas e grupos que o recorte por sua inserção numa relação de dominaçāo determinada, por uma vinculaçāo espacial qualquer, por uma determinada maneira de dispor do produto do seu trabalho, por particularidades étnicas ou religiosas, separava politicamente.

Com a legislaçāo, o problema da identidade, fundamental ao reconhecimento político, tomou-se mais complexo. Ao introduzir figuras jurídicas novas (parceiro, arrendatário, assalariado, etc.), e fazer com que o trabalhador fosse obrigado a assumi-las para o exercício das novas práticas introduzidas em sua vida pela previdência, pelos tribunais, pelo próprio sindicato, a legislação contribuía para a ruptura das identidades "tradicionais" e abria a possibilidade de uma dispersão de identidades. $O$ problema foi agravado pela censura governamental ao uso do termo "camponês". O movimento sindical dos trabalhadores nurais conseguiu, todavia, realizar a proeza política de, desvencilhando-se da diversidade de termos que eram utilizados pelos organismos oficiais, de campônio a rurícola, apropriar-se eficazmente daquele que era simultaneamente 0 mais neutro (porque genérico) e o menos neutro (pela referência ao trabalho) - trabalhador rural - e inculcá-lo em suas bases, adotando-o como um termo "naturalmente" genérico para unir todos os que vivem do trabalho da terra, posseiro ou pequeno proprietário, arrendatário ou parceiro, assalariado permanente ou temporário, e fazendo-se reconhecer pelas demais forças sociais como o seu representante.

Nesse processo, us trabalhadores rurais foram amadurecendo um projeto próprio de reforma agrária que contrapunham às políticas elaboradas pelo Governo militar. Projeto próprio nāo significa projeto elaborado, no isolamento, por um pequeno grupo de iluminados, nem, muito menos, um projeto que tenha brotado espontaneamente das bases. Trata-se de uma construçāo que se vai esboçando ao longo dos anos, em cima de exigências postas pelas lutas desenvolvidas em vários níveis, cristalizando-se em conclusóes de encontros, seminários, tomadas de posiçāo, declaraçōes, etc., incorporando análises produzidas por intelectuais e avaliações dos que ocupam posições-chave no movimento, que acabam sendo sistematizadas por ocasiāo de grandes eventos, como $03^{\circ}$ Congresso Nacional dos Trabalhadores Rurais, em 1979, e 0 4 Congresso, em

Outra presença importante, ao longo desses anos, seria a da Igreja Cat6lica. A rigor, a Igreja, como instituiçāo, sempre esteve presente no campo (...). De suporte

das formas tradicionais de dominaçāo passou a suporte de contestaçāo camponesa,....
1985, e assumidas como suas - diferencialmente, como em qualquer operaçāo desse tipo - por trabalhadores e lideranças nas várias instâncias de organizaçāo sindical. Quando, em 1979, à época da abertura do Governo Figueiredo, o $3^{\circ}$ Congresso Nacional dos Trabalhadores Rurais (maio/79), patrocinado pela Confederação Nacional dos Trabalhadores na Agricultura (CONTAG), propôs a sua "reforma agrária ampla, massiva, imediata e com a participaçäo dos trabalhadores" e associou reforma agrária e democracia, criou um espaço novo para a discussão deste tema e, pela ausência de interlocutores naquele momento, o ocupou por inteiro. Periodo de reorganização partidária, nenhum partido tinha condiçōes de propor (pelo distanciamento do problema e pelo grau de 
detalhamento de uma proposta que sistematizava uma experiência vivida) alguma coisa que se aproximasse do projeto do Movimento Sindical dos Trabalhadores Rurais ${ }^{16}$.

Esse espaço tendeu a ampliar-se entre 1979 e 1984, com a nova orientação adotada pelo movimento sindical de dar prioridade às lutas coletivas. Mobilizaçōes sem precedentes em torno de preços mínimos e outros itens da política agrícola, previdência social, articulaçāo das lutas em torno da terra, greves de assalariados, protestos de massa contra a construção de barragens ou pela exigência de indenizaçāo em terras, manifestações públicas em torno de problemas como secas e barragens ou exigindo simplesmente a reforma, sucederam-se, afirmando a presença do movimento sindical e delimitando um campo de lutas bem mais amplo que a simples oposição entre camponeses e latifundiários.

No período pré-64, em que pesasse a importância da mobilização campo- , nesa, a reforma agrária permanecia sendo, nos termos de Octavio Ianni, "uma questāo posta pela cidade; posta no horizonte do partido, ou dos partidos, e que tem a ver com um entendimento da questão da terra que não é propriamente o do camponês, e que acaba sendo o do camponês, em certa medida" (IANNI, 1983, p. 64). Na verdade, o que se dava era o encontro de um discurso urbano com a mobilização camponesa e a reapropriação desse discurso pelo campesinato que emergia politicamente, sem que essa reelaboração se completasse antes de 1964. Se a reforma agrária era posta e até exigida pela mobilização camponesa, ela era formulada por uma multiplicidade de programas partidários, projetos de lei, etc., que competiam pelo encontro da fómula mais adequada, ao mesmo tempo que competiam pelo enquadramento do campesinato que emergia como força política (GRYNSPAN, 1987).

Nos anos recentes, diferentemente do passado, a reforma agrária seria posta pelo movimento dos trabalhadores rurais e por um poderoso aliado, a Igreja Católica que, desde meados dos anos 70, voltara a preocupar-se com o problema agrário, envolvendo-se diretamente na organização dos trabalhadores, em especial nas áreas de expansão da fronteira agrícolà do norte e do centrooeste. Invertia-se o sentido das coisas, comparativamente aos anos 50 e 60: ao invés da bandeira da reforna agrária ser objeto da conscientização dos camponeses promovida por umma elite urbana, o problema agora era as organizações de trabalhadores venderem a uma cidade também transformada a idéia de reforma agrária e conseguirem, junto com forças urbanas, levar o Governo a realizá-la. É significativo que tenha sido criada em 1982 uma Campanha Nacional pela Reforma Agrária cujos promotores e integrantes eram, não os partidos políticos ou os sindicatos urbanos, mas a Confederação Nacional dos Trabalhadores na Agricultura, a Comissāo Pastoral da Terra, a Linha 6 da Conferência Nacional dos Bispos do Brasil e duas pequenas organizaçōes de intelectuais pró-reforma agrária: a Associaçāo Brasileira de Reforma Agrária (ABRA) e o Instituto Brasileiro de Análises Sociais e Econômicas (IBASE) que propunham às forças sociais tornar "a Reforma Agrária uma bandeira e um movimento concreto de toda a sociedade em apoio à Luta dos trabalhadores rurais".

16 As conclusōes do 3\% e do 4\% Congresso Nacional dos Trabalhadores Rurais, além de reivindicaçōes sobre a reforma agrária e a política agricola propriz mente ditas, incluem propostas articuladas sobre colonizaçāo, terras públicas, incentivos fiscais, grandes obras públicas, Justiça Agrária, seca, projetos especiais. Tratam zinda das questōes trabalhistas e previdenciárias e fazem consideraçōes sobre o modelo económico e a política nacional. 


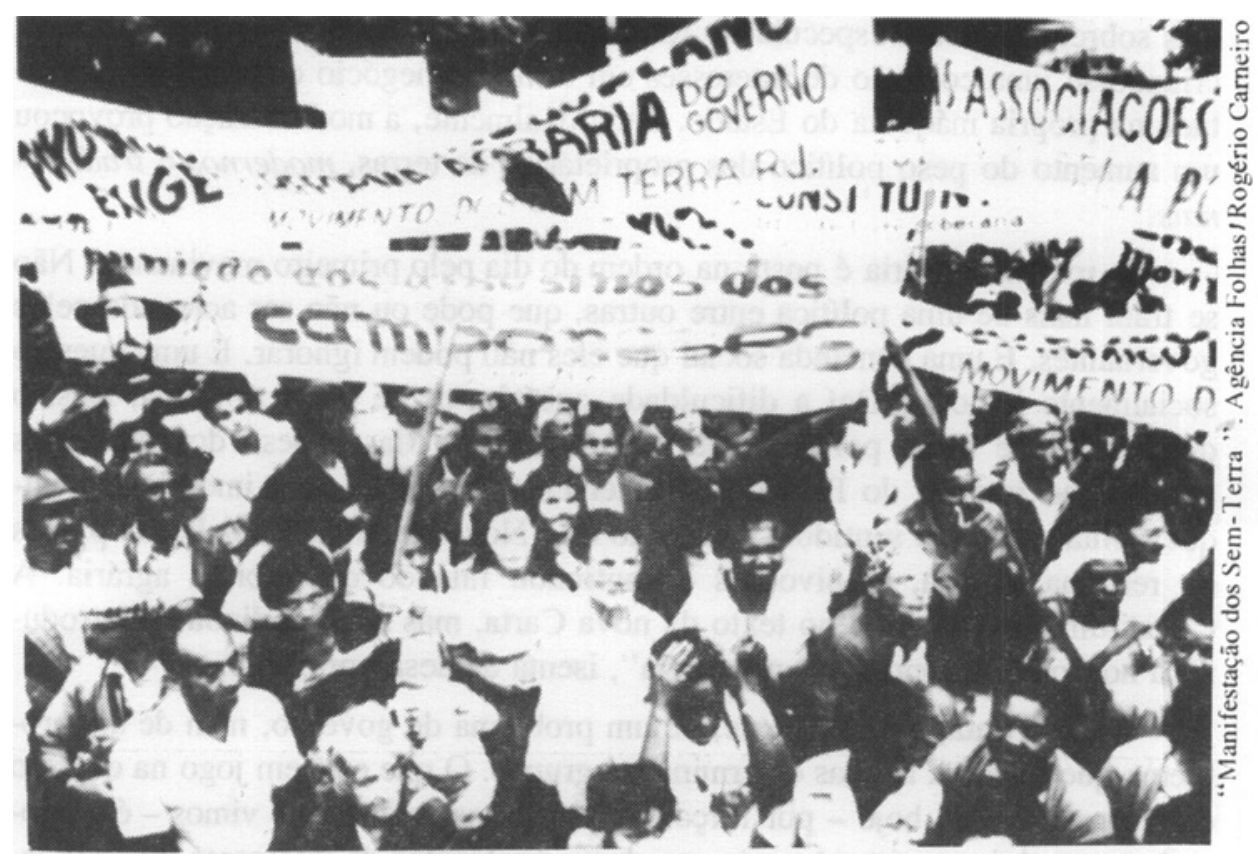

A Reforma Agrária como Questão

Se o que vimos até aqui faz algum sentido, poderíamos concluir, negativamente, que as mudanças sofridas pela sociedade brasileira, nas últimas décadas, não se limitaram à sua economia, e nem as mudanças na sua economia se limitaram ao campo, e nem as mudanças sofridas pelo campo se limitaram à agricultura, e nem as mudanças na agricultura foram apenas econômicas, e nem as mudanças econômicas no setor agrícola se restringiram à modernização tecnológica ou à integração ao mercado ou à integração ao complexo agroindustrial e, finalmente, nem as mudanças sofridas pelo setor agrícola para além da modernizaçāo se limitaram aos seus efeitos perversos.

As transformaçōes ocorridas no campo foram maiores que a modernizaçâo, valorada positivamente, e os seus efeitos, lamentados e, algumas vezes, justificados pelos que a estudam. Procuramos mostrar alguns dos processos que, paralelamente à modernização, pesaram na transformação do perfil do setor agrário brasileiro.

A colocação em evidência desses processos sugere que eles se combinam em dois movimentos relativamente autônomos e contraditórios. Por um lado, a progressiva ilegitimação das formas tradicionais de dominação, associada à incapacidade do Estado - um Estado que não é apenas árbitro, mas parte nas lutas sociais - de gerar novas formas de legitimidade que têm levado à multiplicação dos conflitos e à ampliação do seu “âmbito". Não são mais apenas conflitos em torno da terra, da produção ou das condiçōes de trabalho, mas também da construção de obras públicas, da assistência governamental nas situações de calamidade, do meio ambiente, da assistência médica, etc. Não mais são apenas conflitos que envolyạm tão somente camponeses e latifundiários e, muito menos, que se resolvam apenas entre eles.

Por outro lado, as vantagens asseguradas pelo Estado, no bojo da política de modernização, atraíram para as atividades agropecuárias e agroindustriais, 
mas sobretudo para a especulaçāo fundiária, capitais das mais diversas origens, criando-se uma coalizão de interesses em torno do negócio com a terra incrustada na própria máquina do Estado. Paradoxalmente, a modernização provocou um aumento do peso político dos proprietários de terras, modernos e tradicionais.

A reforma agrária é posta na ordem do dia pelo primeiro movimento. Não se trata mais de uma política entre outras, que pode ou não ser acionada pelos governantes. É uma demanda social que eles não podem ignorar. É uma questão socialmente imposta. Daí a dificuldade que têm de se livrar do tema, mesmo quando ele se torna politicamente inconveniente. Mas o peso dos interesses agrários no interior do Estado é suficientemente grande para imobilizar qualquer tentativa nesse sentido. O governo da "Nova República" elaborou planos de reforma agrária, arquivou-os e continuou falando de reforma agrária. A Constituinte inscreveu-a no texto da nova Carta, mas a inviabilizou ao introduzir a noção de "propriedade produtiva", isenta de desapropriação.

Não se trata, simplesmente, de um problema de governo, nem de um problema que envolva apenas determinados grupos. O que está em jogo na questão da reforma agrária hoje - por força dos processos sociais que vimos - é a oposição entre dois movimentos que envolvem confrontos de interesses diversificados e que, por assim dizer, atravessam toda a sociedade. Nesses confrontos, 0 que, por sua vez, está em jogo é a própria maneira de operar do Estado. $O$ impasse do Estado em administrar essa questāo socialmente construída reflete também aquele da sociedade em escolher o Estado que deseja para gerir os seus próprios impasses.

\section{Referências Bibliográficas}

ABBOTT, M. L. 1988. Fundo Fiscal absorveu US $\$ 6,6$ bilhões em 10 anos. Jornal do Brasil, 28/04, $1^{2}$ caderno.

ALMEIDA, A. W. B. 1977. Êxodo: uma tradição paralela. In: PALMEIRA, M. e ALMEIDA, A. W. B. A invenção da migração. Projeto emprego e mudança sócio-econômica no Nordeste. Rio de Janeiro, Museu Nacional/UFRJ (mimeografado).

1980. G.E.T.A.T. A segurança nacional e o revigoramento do poder regional. Rio de Janeiro, CPT - Maranhão.

ALMEIDA, A. W. B. e ESTERCI, N. 1979. Trabalho e subordinação no sertão cearense. Revista de Ciências Sociais, 10 (1/2): 95-130.

BASTOS, E.C.G. 1977a. Laranja e lavoura branca. Rio de Janeiro, Programa de PósGraduação em Antropologia Social/Museu Nacional/UFRJ. Dissertação de Mestrado.

1977b. Relações sociais no cultivo do algodão no Sertão. Projeto emprego e mudança sócio-econômica no Nordeste. Convênio UFRJ/FINEP/IPEA (mimeografado).

-1964. Lei no 4.504, de 30 de novembro.

BOURDIEU, P. 1966. Condition de classe et position de classe. Archives Européenes de Sociologie, VII.

CAMARGO, A. A. 1981. A questão agrária: crise de poder e reformas de base (1930-1964). In: FAUSTO, B., org. História geral da civilização brasileira - Tomo III - O Brasil republicano. $3^{\circ}$ volume. Sociedade e Política (1930-1964). São Paulo, Difel. 
CARDOSO, F. H. 1975. Autoritarismo e democratização. Rio de Janeiro, Paz e Terra.

CHIARELLI, C. A. G. 1972. Teoria e prática do PRORURAL. São Paulo, LTr.

CORADINI, O. L. 1982. Produtores, cooperativismo empresarial e multinacionais: o caso do trigo e da soja. In: CORADIANI, O. L. e FREDERICO, A. Agricultura, cooperativas e multinacionais. Rio de Janeiro, Zahar.

-1988. Representaçōes sociais e conflitos nas pollticas de saúde e previdência social rural. Rio de Janeiro, Programa de Pós-Graduação em Antropologia Social/Museu Nacional do Rio de Janeiro. Tese de Doutorado.

CORREIA DE ANDRADE, M. 1964. A terra e o homem no Nordeste. 2. ed São Paulo, Brasiliense.

DELGADO, G. C. 1985. Capital financeiro e agricultura no Brasil: 1965-1985. São Paulo, f́cone/UNICAMP.

DREIFUSS, R. A. 1981. 1964: a conquista do Estado. Petropolis, Vozes.

ESTERCI, N. 1985. Conflito no Araguaia: peōes e posseiros contra a grande empresa. São Paulo, USP. Tese de Doutorado.

FIBGE - Fundação Instituto Brasileiro de Geografia e Estatistica. 1979. Indicadores sociais - relatório 1979. Rio de Janeiro, FIBGE.

-1986-1987. Estattsticas históricas do Brasil. Séries econômicas, demográficas e sociais - 1550 a 1985. Rio de Janeiro, IBGE.

FIGUEIREDO, V. 1984. Modernização sem reforma: uma solução precária para a questâo agrária no Brasil. Tempo Brasileiro, (77) abril/junho.

FURTADO, C. 1964. Dialética do desenvolvimento. Rio de Janeiro/São Paulo/Lisboa, Fundo de Cultura.

GARCIA, M. F. 1984. Feira e trabalhadores rurais. Rio de Janeiro, Programa de P6sGraduação em Antropologia Social/Museu Nacional/UFRJ. Tese de Doutorado.

GARCIA Jr., A. 1975. Terra de trabalho. Rio de Janeiro, Programa de P6́s-Graduaçāo em Antropologia Social/Museu Nacional/UFRJ. Dissertaçăo de Mestrado.

- 1983. O Sul: caminho do roçado. Rio de Janeiro, Programa de Pós-Graduaçáo em Antropologia Social/Museu Nacional/UFRJ. Tese de Doutorado

1986. Libres et assujettis: la transition des travailleurs dépendants aux travailleurs libres dans le Nord-Est du Brésil. Actes de la Recherche en Sciences Sociales, (65), novembro.

1987. Industrializaçäo e transformaçôes sociais no campo. Rio de Janeiro, Museu Nacional.

GRABOIS, G. P. 1971. Nova Imperatriz - estudo preliminar. Rio de Janeiro, PPGAS/Museu Nacional/UFRJ. Simpósio de Pesquisas, mimeografado.

GRAHAM, D. H. et al. 1987. Thirty years of agricultural growth in Brazil: crop performance, regional profile, and recent policy review. Economic Development and Cultural Change, 36 (1): 1-34, oct.

GRAZIANO DA SILVA, J. coord., 1978. Estrutura agrária e produção de subsistência na agricultura brasileira. São Paulo, Hucitec.

-1982. A modernizaçāo dolorosa. Rio de Janeiro, Zahar.

1987. Mas, qual Reforma Agrária? Reforma Agrária, 17, (1), abril/julho.

GRYNSPAN, M. 1987. Mobilizaçāo componesa e competição politica no Estado do Rio de Janeiro (1950-1964). Rio de Janeiro, Programa de P6s-Graduaçăo em Antropologia Social/Museu Nacional/UFRJ. Dissertaçấo de Mestrado.

HEREDIA, B. 1986. As transformaçōes sociais na "plantation" canavieira: o caso do sul de Alagoas. Rio de Janeiro, Programa de Pós-Graduação em Antropologia Social/Museu Nacional/UFRJ. Tese de Doutorado.

IANNI, O.' 1983. Intervençáo na mesa-redonda: os anos 60: reforma agrária e questáo agrária no período populista. Anais do Seminário Revisão Crttica da Produção Sociolbgica Voltada para a Agricultura. Sáo Paulo, 24-25 de março.

KAGEYAMA, A. 1986. O trabalhador temporário na agricultura em 1980. Reforma agrária, 15 (4), jan-mar. 
MARTINE, G. 1984. Os dados censitários sobre migraçôes internas: evoluçâo e utilização. In: ABEP (Associação Brasileira de Estudos Populacionais). Censos consensos contra-sensos. Anais do III Seminário Metodol6gico dos Censos Demográficos. Ouro Preto, ABEP/Fundaçāo Ford.

MARTINS, J. S. 1980. Expropriação e violência: a questâo politica no campo. São Paulo, Hucitec.

1981. Os camponeses e a política no Brasil. Petrópolis, Vozes.

1984. A militarização da questão agrária no Brasil. Petrópolis, Vozes.

1985. A igreja face à política agrária do Estado. In: PAIVA, V., org. Igreja e questão agrária. São Paulo, Loyola.

1986. A reforma agrária e os limites da democracia na "Nova República". São Paulo, Hucitec.

MARX, K. 1950. Le Capital. Tomo Iri. Paris, Éditions Sociales.

MÜLLER, G. 1988. Ambivalência da modernização agrária. Novos Estudos - CEBRAP, (21) julho.

NUNES LEAL, V. 1976. Coronelismo, enxada e voto. 2. ed., São Paulo, Alfa-Omega.

PALMEIRA, M. 1971. Feira e mudança econômica. Rio de Janeiro, Simpósio de Pesquisas - Programa de Pós-Graduação em Antropologia Social/Museu Nacional/UFRJ (mimeografado).

1976. Casa e trabalho: nota sobre as relações sociais na "plantation tradicional". In: XLII ${ }^{\mathrm{e}}$ CONGRÈS INTERNATIONAL DES AMERICANISTES. Actes. Paris, 2-9 setembro.

- 1979. Desmobilização e conflito, relaçōes entre trabalhadores e patrōes na agroindústria pernambucana. Revista de Cultura e Política, São Paulo, ano 1 (1), agosto.

- 1985. A diversidade da luta no campo: luta camponesa e diferenciação do cam:pesinato. In: PAIVA, V., org. Igreja e questāo agrária. Sāo Paulo, Loyola.

1987. Reforma agrária e constituição. Ciência Hoje, (35), setembro.

PEIXOTO, H. R. et al. 1979. A soja na pequena agricultura. Brasília, BINAGRI.

PEREIRA DE QUEIROZ, M. I. 1978. Cultura, sociedade rural, sociedade urbana: ensaios. Rio de Janeiro/São Paulo, Livros técnicos e científicos/EDUSP.

RAPOSO, B. F. S., org. 1960. Serviço social rural. Rio de Janeiro, Ed. Serviço Social Rural.

SIGAUD, L. 1979. Os clandestinos e os direitos. São Paulo, Duas Cidades.

1983. As vendas de ponta de rua. Anuário Antropológico, 81. Rio de Janeiro, Tempo Brasileiro.

-1986. Efeitos sociais de grandes projetos hidrelétricos: as harragens de Sobradinho e Machadinho. Comunicação n" 9, Museu Nacional, UFRJ.

SIGAUD, L. et al. 1987. Expropriação do campesinato e concentraçâo de terras em Sobradinho: uma contribuiçăo à análise dos efeitos da política energética do Estado. Ciências Sociais Hoje. Sâo Paulo, Vértice/ANPOCS, 1987.

SILVA Jr., A. et al. 1984. Emprego rural: uma análise crítica das categorias dos censos agropecuários e das estatísticas cadastrais. Revista Brasileira de Estatística, 45 (179/180) jul/dez.

SORJ, B. 1980. Estado e classes sociais na agricultura brasileira. Rio de Janeiro, Zahar.

VEJA. 1989. São Paulo, ano 22, n. 38, setembro.

VELHO, O. G. 1972. Frentes de expansão e estrutura agrária. Rio de Janeiro, Zahar.

ZANATTA, O. 1984. A titulação de terra rural no Brasil. In: SIMPÓSIO INTERNACIONAL DE EXPERIÊNCIA FUNDIÁRIA. Salvador, Bahia, 20-24 de agosto. Anais. Brasília, INCRA.

Moacir Palmeira é professor de Antropologia Social do Museu Nacional (RJ) e participante do Ciclo de Seminários "Cem anos de República: continuidade e mudança", 1989, do IEA. 